\title{
Changes in developmental assets across a 4-month competitive season among youth basketball players
}

\section{Mudanças nos ativos de desenvolvimento em uma temporada competitiva de quatro meses entre os jovens jogadores de basquete}

\author{
Felipe G. Mendes ${ }^{1}$ \\ (D) https://orcid.org/0000-0001-9552-754X \\ André L.A. Soares \\ (D) https://orcid.org/0000-0001-6629-656X \\ Ahlan B. Lima ${ }^{1}$ \\ (iD) https://orcid.org/0000-0001-8691-5719 \\ Carlos E. Palheta \\ (D) https://orcid.org/0000-0001-7066-7562 \\ Luisa D. Kós \\ (D) https://orcid.org/0000-0002-2280-6262 \\ Fabricio J. Milan \\ (iD) https://orcid org/0000-0003-1724-3722 \\ Carine Collet 1,2 \\ (D) https://orcid.org/0000-0003-3742-4037 \\ Humberto M. Carvalho 1 \\ (iD http://orcid.org/0000-0002-2855-0296
}

Abstract - The present study examined the changes in developmental assets among young basketball players during a 4-month competitive period, accounting for variation by age group. Additionally, we examined the age-related variation on developmental assets. Sixtyfive adolescent basketball players aged between 9.5 to 17.3 years were considered. We used the Portuguese version of the Developmental Assets Profile Questionnaire. Multilevel modeling was used to estimate the magnitude of changes on developmental assets across the 4-month competitive season, as well as aligning assets scores by chronological age. Positive values and positive identity scores were substantially increased after the 4-month competitive sample. The other assets scores showed no variation across the competitive 4-month competitive season, independent of age group. There was a trend of linear decrease in developmental assets as the adolescent players got older. For positive values, there was a non-linear trend with a higher decrease rate between about 10 to 14 years, levelling off thereafter. Developmental assets did not appear to be influenced by exposure to a period of organized training and competition among adolescent basketball players. Hence, the observed decrease on developmental assets when aligning by age may reflect the influence of contextual and cultural environments of practice. This is of particularly interest for positive values, which refer to school engagement or and social justice, qualities that are not sport-specific but assume a key and importance position in sport participation for a positive role in youth development.

Key words: Adolescents; Multilevel analysis; Psychology developmental; Training; Youth sports.

Resumo - O presente estudo examinou as mudanças nos ativos de desenvolvimento entre jovens jogadores de basquetebol durante um periodo competitivo de 4 meses, considerando a variaçẫo por faixa etária. Adicionalmente, examinou-se a variação da idade no desenvolvimento dos Ativos. Participaram deste estudo 65 adolescentes jogadores de basquetebol com idade entre 9.5 a 17.3 anos. Utilizou-se a versão em português do Questionário de Perfil de Ativos de Desenvolvimento. O modelo multinivel foi usado para estimar a magnitude das mudanças nos ativos de desenvolvimento, bem como alinhar as pontuaçôes dos ativos por idade cronológica. Os valores de valores positivos e de identidade positiva foram aumentados após 4 meses competitivos. Já os outros não mostraram variação na mesma temporada, independente da faixa etária. Houve uma tendência de diminuição linear nos ativos de desenvolvimento à medida que os adolescentes se tornaram mais velhos. Para os valores positivos, houve uma tendência não linear com uma taxa de decréscimo mais alta entre cerca de 10 a 14 anos, nivelando-se depois disso. Os ativos de desenvolvimento não parecem ser influenciados pela exposiçâo a um período de competição entre jogadores de basquete adolescentes. Assim, a diminuição nos ativos de desenvolvimento ao alinhar pela idade pode refletir a influência dos contextos culturais e de prática. Isto é particularmente interessante para valores positivos, que se referem ao envolvimento escolar ou à justiça social, qualidades que não são específicas do esporte, mas que assumem uma posição chave e importante na participação esportiva para desenvolvimento positivo da juventude.

Palavras-chave: Adolescentes; Esportes juvenil; Modelo multinivel; Psicologia do desenvolvimento; Treinamento.
1 Universidade Federal de Santa Catarina. Florianópolis, SC. Brasil

2 Universidade do Estado de Santa Catarina. Florianópolis, SC. Brasil

Received: 24 October 2018 Accepted: 09 May 2019

How to cite this article Mendes FG, Soares ALA, Lima AB, Palheta CE, Kós LD, Milan FJ, Collet C, Carvalho HM. Changes in developmental assets across a 4-month competitive season among youth basketball players. Rev Bras Cineantropom Desempenho Hum 2019, 21:e59757. D0I: http://dx.doi. org/10.1590/1980-0037.2019v21e59757

Copyright: This work is licensed under a Creative Commons Attribution 4.0 International License. 


\section{INTRODUCTION}

Young athletes' development promotes the interaction between individuals' performance, abilities, skills and competences for their positive development ${ }^{1}$. Developmental assets comprise relationships, opportunities provided by adults and peers, values, skills, abilities, and a positive self-perception developed over time ${ }^{2}$. Therefore, assets can be understand as 'building blocks' for human development, promoting thriving, resilience and reduced risk behaviors ${ }^{3-6}$. Assets need to be considered as the outcome of youth interactions with themselves ${ }^{6}$ and within their context ${ }^{5}$, combining learning commitment, positive values, social competencies, positive identity, support, empowerment, boundaries, expectations, and the constructive use of time. Positive youth coach supervision within sport participation programs potentially provide a powerful context to promote environments linked to various positive aspects of healthy development throughout life $\mathrm{f}^{7,8}$.

In general, youth sports programs are focused on performance development. However, an holistic approach to the athletes' development needs to be considered ${ }^{9,10}$, including changes in young athletes' to favor both societal and individual welfare ${ }^{11}$. Considering team-sports, youth basketball in particular, interactions within the team may present a potential positive role in the developmental process, extending from personal and immediate outcomes such as enjoyment, positive expectations, and personal assets and skills to more long-term and distant positive effects ${ }^{12}$.

However, the available information considering young athletes' development during pubertal years, particular adopting repeated measures, is limited. In basketball, as generally among other youth sports competitions and training groups, athletes are grouped by one- or two- chronological age groups. Therefore, in the present study we examined the changes in developmental assets among young basketball players across a 4-month competitive period, considering possible variation between age group. Considering the repeated measures design adopted, we examined the trend of changes of developmental assets between the ages of 10 to 17 years.

\section{METHOD}

\section{Participants and experimental design}

Sixty-five adolescent basketball players aged between 9.5 to 17.3 years at the baseline of the observation were considered. Follow-up measures were performed after the players were exposed to a 4-months competitive season. The players were engaged in a structured basketball youth training program from a club within the metropolitan region of São Paulo (Mauá, São Paulo, Brazil), which competed at state level under the supervision of the Federação Paulista de Basketball (S. Paulo Basketball Federation). Within the club players were grouped by age category teams (under-11, under-13, under-15 and under-17), being engaged in six to ten hours of training per week according to their age group. 
Participation in this study was voluntary, and players and their parents or legal guardians provided informed written consent. The study was approved by the Research Ethics Committee of the University of Campinas and was conducted in accordance with recognized ethical standards ${ }^{13}$.

\section{Procedure}

Chronological age was calculated considering the difference between date of birth and date of baseline observation to the nearest 0.1 year.

We used the Portuguese version of the Developmental Assets Profile (DAP) questionnaire ${ }^{14,15}$. The questionnaire is composed of 58 items, rated on a Likert type scale as follows: 'Not at all or rarely' (1), 'Somewhat or Sometimes' (2), 'Very Often' (3) and 'Extremely or almost always' (4). The questionnaire structure includes information about external and internal factors from a personal perspective, such as, support (4 items), boundaries and expectations (5 items), commitment to learning (4 items), positive values ( 3 items), and positive identity ( 5 items).

\section{Statistical Analysis}

Multilevel modeling was used to examine variation on developmental assets between measures at baseline and across the 4-month competitive season. We considered a hierarchical structure, where measurements (level 1) to be nested by players (level-2), that were nested by age group (level-3). In the first step of the analysis we allowed for players' scores (level 2) and grouped by age-group (level-3) were allowed to vary at baseline and in the rate of change between measures at baseline and post 4-month competitive season.

In the second step of the analysis we took advantage of the mixedlongitudinal design available, and explored whether there was a trend of changes on developmental assets across the age range of observation. Hence we modeled each assets score by chronological age. For modeling convenience, we centered age at grand mean, i.e., 13.8 years. We allowed for the shape of changes to be non-linear including by fitting a quadratic polynomial, which is age term squared. Intercept (i.e., score at the minimum age observed), centered age and squared age terms were allowed to vary at level-2 (between players). Estimations were performed using lme function from the "nlme" ${ }^{16}$ package in $\mathrm{R}$ statistical language $\mathrm{e}^{17}$.

\section{RESULTS}

Mean scores and uncertainty estimates pre- and post- 4-months competitive for assets scores accounting for variation by age group are given in Table 1. Positive values and positive identity scores were substantially increased after the 4-month competitive sample. The other assets scores showed no variation across the competitive 4-month competitive season, accounting for age group variation. There was substantial variation between age group for positive values, learning commitment, and boundaries and expectations, although variation was constant with the 4-month competitive season. 
Figure 1 shows the trends of variation of developmental assets across adolescent years among the basketball players. There was a trend of substantial linear decrease in developmental assets as the adolescent players got older, except for positive values. In this case we observed a non-linear trend. A higher decrease rate between about 10 to 14 years was observed levelling off thereafter.
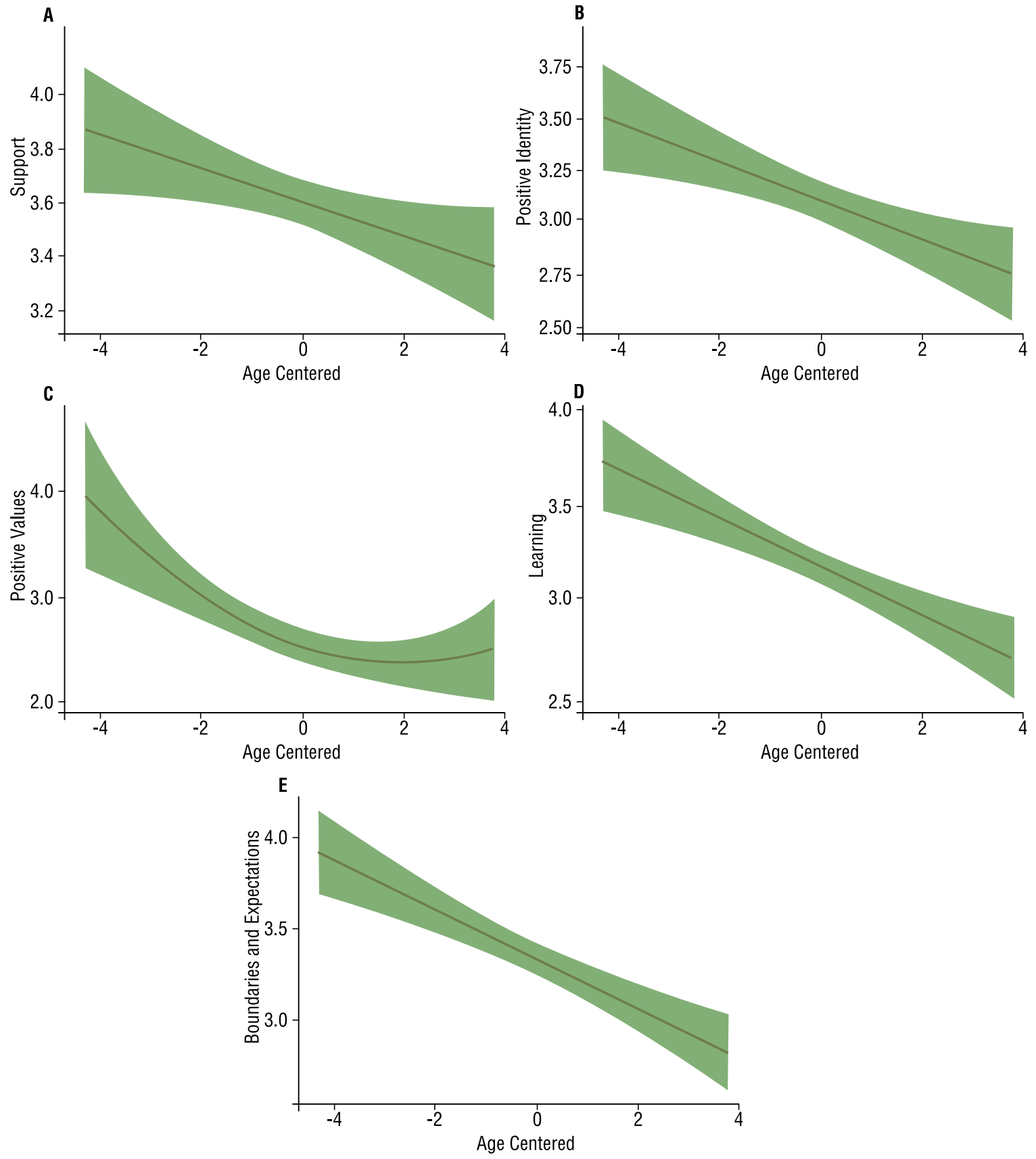

Figure 1. Variability of DAP factors by chronological age.

\section{DISCUSSION}

In the present study we examined the changes in developmental assets 
Table 1. Multilevel regression analysis of changes DAPs pre- and end-season in adolescent basketball players. $(n=65)$

\begin{tabular}{|c|c|c|c|c|c|c|}
\hline & \multicolumn{3}{|c|}{$\begin{array}{c}\text { Fixed effects } \\
\text { (95\% confidence interval) }\end{array}$} & \multicolumn{3}{|c|}{$\begin{array}{c}\text { Random effects } \\
\text { (95\% confidence interval) }\end{array}$} \\
\hline & Pre-Season & Post-season & $\begin{array}{l}\text { Changes across } \\
\text { the 4-months season }\end{array}$ & $\begin{array}{l}\text { Level-1 standard } \\
\text { deviation }\end{array}$ & $\begin{array}{l}\text { Level-2 standard } \\
\text { deviation }\end{array}$ & $\begin{array}{l}\text { Level-3 standard } \\
\text { deviation }\end{array}$ \\
\hline \multicolumn{7}{|l|}{ Assets } \\
\hline Positive values & $\begin{array}{c}2.55 \\
\text { (2.26 to } 2.84)\end{array}$ & $\begin{array}{c}2.76 \\
\text { (2.47 to } 3.05)\end{array}$ & $\begin{array}{c}0.21 \\
(0.00 \text { to } 0.41)\end{array}$ & $\begin{array}{c}0.54 \\
(0.45 \text { to } 0.65)\end{array}$ & $\begin{array}{c}0.53 \\
(0.39 \text { to } 0.71)\end{array}$ & $\begin{array}{c}0.20 \\
(0.06 \text { to } 0.65)\end{array}$ \\
\hline Support & $\begin{array}{c}3.59 \\
\text { (3.46 to } 3.72)\end{array}$ & $\begin{array}{c}3.58 \\
(3.46 \text { to } 3.71)\end{array}$ & $\begin{array}{c}-0.01 \\
(-0.14 \text { to } 0.12)\end{array}$ & $\begin{array}{c}0.35 \\
(0.29 \text { to } 0.42)\end{array}$ & $\begin{array}{c}0.34 \\
(0.25 \text { to } 0.46\end{array}$ & - \\
\hline $\begin{array}{l}\text { Learning } \\
\text { commitment }\end{array}$ & $\begin{array}{c}3.16 \\
\text { (2.90 to } 3.40)\end{array}$ & $\begin{array}{c}3.19 \\
\text { (2.94 to } 3.44)\end{array}$ & $\begin{array}{c}0.03 \\
(-0.10 \text { to } 0.17)\end{array}$ & $\begin{array}{c}0.37 \\
(0.31 \text { to } 0.44)\end{array}$ & $\begin{array}{c}0.30 \\
(0.21 \text { to } 0.43)\end{array}$ & $\begin{array}{c}0.21 \\
(0.08 \text { to } 0.53)\end{array}$ \\
\hline Positive identity & $\begin{array}{c}3.02 \\
\text { (2.88 to } 3.16)\end{array}$ & $\begin{array}{c}3.17 \\
\text { (3.03 to } 3.30)\end{array}$ & $\begin{array}{c}0.15 \\
(0.02 \text { to } 0.27)\end{array}$ & $\begin{array}{c}0.32 \\
(0.26 \text { to } 0.38)\end{array}$ & $\begin{array}{c}0.42 \\
(0.33 \text { to } 0.53)\end{array}$ & - \\
\hline $\begin{array}{l}\text { Boundaries and } \\
\text { expectations }\end{array}$ & $\begin{array}{c}3.28 \\
(3.06 \text { to } 3.50)\end{array}$ & $\begin{array}{c}3.33 \\
\text { (3.11 to } 3.54)\end{array}$ & $\begin{array}{c}0.04 \\
(-0.07 \text { to } 0.16)\end{array}$ & $\begin{array}{c}0.32 \\
(0.26 \text { to } 0.38)\end{array}$ & $\begin{array}{c}0.39 \\
(0.30 \text { to } 0.50)\end{array}$ & $\begin{array}{c}0.17 \\
(0.05 \text { to } 0.52)\end{array}$ \\
\hline
\end{tabular}

among young basketball players across a 4-month competitive period, accounting for variation by age group. Increases in positive values and positive identity were observed after exposure to the 4-month competitive season. At least personal development dimensions appear susceptible to be influenced by the short-term influence of exposure to organized training and competition among adolescent basketball players aged 10 to 17 years. Overall these observations support the potential benefits of engagement in organized youth sports programs.

Developmental assets score, on average, were lower compared to available data with young athletes ${ }^{7,18}$. However, the present results were somewhat higher than comparable data of Brazilian underserved adolescents exposed to extra-curricular sports programs ${ }^{11}$. It is apparent that exposure to organized sports and the social community environment contribute substantially to the development of the adolescent assets. Moreover, the present data provides a support that exposure to organized sports may be a useful context to promote the development of personal life skills transferable to other areas of life ${ }^{19}$. Even considering the competitive nature of organized youth basketball programs, it was apparent a positive effect on both positive values and positive identity. Hence, potential benefits related to school engagement or equality and social justice and qualities, often not sport-specific, may assume an important position of sport participation to claim for a positive role in youth development ${ }^{6}$.

It is claimed that organized youth sports may be favorable to a positive youth development purpose with a supportive and positive environment of teaching, learning, playing and competition ${ }^{20,21}$. Altogether, available information suggests that the context of youth sports delivery may have an impact on developmental assets. Hence, the process of positive to youth development in the sports need to further understand the context of training, as well as players life outside sports, particularly in socio-economically vulnerable contexts ${ }^{11,22}$.

A marked trend of decrease in developmental assets across adolescence was observed. These results were consistent with the limited available data 
in young soccer players ${ }^{18}$. These results in youth sports contexts may reflect the highly selective and exclusive character of sports as competitive level increases with age ${ }^{23}$. Its appears reasonable that the young athletes may perceive their performance level changes in comparison with their peers and their prospects of a future career in sports in adult years. Consequently, the coaches should be aware of the need the changes of the young athlete personal and contextual perceptions as they grow and develop within the sport.

Likely maturity associated variation on performance level ${ }^{24}$ and behavioral characteristics ${ }^{25}$ may influence developmental assets. In the present study were did not consider maturity indicators, as the only method available for us was the maturity offset ${ }^{26}$, but given the wide range of age in our sample the method would provide unreliable estimations. Also, future studies should consider the influence of accumulated training experience and functional performance on behavioral characteristics, such as developmental assets. Also, caution is warranted when interpreting and generalizing our data as it represents a mixed longitudinal data with small time unit (four months between repeated measures).

\section{CONCLUSION}

In summary, we examined the changes in developmental assets among young basketball players during a 4-month competitive period, accounting for variation by age group. Developmental assets among adolescent basketball players appear to be sensitive to training and competition exposure among adolescent basketball players. The present study provides valuable information to understand the importance of youth sports programs to positive development of young athletes.

\section{COMPLIANCE WITH ETHICAL STANDARDS}

\section{Funding}

This study was partially supported by the Federação Catarinense de Basketball (Basketball Federation of Santa Catarina). The second and fourth author was supported by a grant of the Coordenação de Aperfeiçoamento de Pessoal de Nível Superior (CAPES). The sixth author was supported by a grant of the Conselho Nacional de Desenvolvimento Científico e Tecnológico (CNPQ).

\section{Ethical approval}

Ethical approval was obtained from the local Human Research Ethics Committee-University of Campinas and the protocol (no. 1.329.389) was written in accordance with the standards set by the Declaration of Helsinki.

\section{Conflict of interest statement}

The authors have no conflict of interests to declare. 


\section{Author Contributions}

Conceived and designed the experiments: HMC, CC, FGM. Performed the experiments: ALAS, HMC. Analyzed the data: FGM, HMC, ALAS. Contributed reagents/materials/analysis tools: ABL, CEP, LDK . Wrote the paper: FGM, HMC, FJM, CC .

\section{REFERENCES}

1. Gullich A. Many roads lead to Rome--developmental paths to Olympic gold in men's field hockey. Eur J Sport Sci 2014;14(8):763-71.

2. Strachan L, Côté J, Deakin J. An Evaluation of Personal and Contextual Factors in Competitive Youth Sport. J Apl-lied Sport Psych 2009; 21(3): 340-55.

3. Benson PL. The Troubled Journey: A Portrait of 6th-12th Grade Youth. 1993.

4. Benson PL. All kids are our kids: What communities must do to raise caring and responsible children and adolescents: Jossey-Bass; 2006.

5. Benson PL. Adolescent development in social and community context: A program of research. New Dir Youth Dev 2002;2002(95):123-48.

6. Benson PL, Scales PC, Syvertsen AK. The contribution of the developmental assets framework to positive youth de-velopment theory and practice. In: Lerner RM, Lerner JV, Benson JB. Advances in Child Development and Behavior; 2011. p. 197-230.

7. Santos AJ, Carvalho HM, Gonçalves CE. Personal and ecological factors in school sport: a multilevel approach. South African J Res Sport Phys Educ Rec 2018;40(1):125-40.

8. Vierimaa M, Erickson K, Côté J, Gilbert W. Positive Youth Development: A Measurement Framework for Sport. In-ter J Sports Sci Coach 2012;7(3):601-14.

9. Carvalho HM, Goncalves CE, Collins D, Paes RR. Growth, functional capacities and motivation for achievement and competitiveness in youth basketball: an interdisciplinary approach. J Sports Sci 2018;36(7):742-8.

10. Piggott B, Muller S, Chivers P, Papaluca C, Hoyne G. Is sports science answering the call for interdisciplinary re-search? A systematic review. Eur J Sport Sci 2018:1-20.

11. Reverdito RS, Galatti LR, Carvalho HM, Scaglia AJ, Cote J, Goncalves CE, et al. Developmental Benefits of Extra-curricular Sports Participation Among Brazilian Youth. Percept Mot Skills 2017;124(5):946-960.

12. Holt N, McHugh T-L, N Tink L, C Kingsley B, Coppola A, Neely K, et al. Developing sport-based after-school programmes using a participatory action research approach. Qual res 2013; 5(3): 332-355.

13. Harriss D, Atkinson G. International Journal of Sports Medicine-ethical standards in sport and exercise science re-search. Int J Sports Med 2009;30(10):701-2.

14. Santos AJ, Gonçalves CE. Tradução do sources of enjoyment in youth sport questionnaire e do developmental assents profile para jovens atletas portugueses. (Ed.). Annals of research in sport And physical activity. Coimbra: Imprensa da Universidade de Coimbra 2012. p.9-36.

15. Search Institute. Developmental Assets Profile User Manual. Minneapolis, MN: Search Institute; 2005.

16. Pinheiro JC, Bates DM. Mixed-effects models with Sand and S-plus. New York: Springer 2000.

17. R Core Team. R: A Language and Environment for Statistical Computing. Vienna, Austria: R Foundation for Statisti-cal Computing; 2015. Available from: http:// www.R-project.org/ [2018 jul 03].

18. Santos AJB, Gonçalves CEB. Efeito da experiência desportiva e do grupo etário na satisfação e nos ativos de desenvol-vimento de jovens futebolistas. Rev Bras Ciênc Esp 2016;38(2):139-48. 
19. Pierce S, Gould D, Camiré M. Definition and model of life skills transfer. Int Rev Sport Exerc Psych 2017;10(1):186-211.

20. Côté J, Hancock DJ. Evidence-based policies for youth sport programmes. Int J Sport Pol Polit 2016;8(1):51-65.

21. Strachan L, Côté J, Deakin J. An evaluation of personal and contextual factors in competitive youth sport. J Applied Sport Psych 2009;21(3):340-55.

22. Reverdito RS, Carvalho HM, Galatti LR, Scaglia AJ, Goncalves CE, Paes RR. Effects of Youth Participation in Ex-tra-Curricular Sport Programs on Perceived Self-Efficacy: A Multilevel Analysis. Percept Mot Skills 2017;124(3):569-83.

23. Gonçalves CE, Rama LM, Figueiredo AJ. Talent identification and specialization in sport: an overview of some unan-swered questions. Int J Sports Phys Perfor 2012;7(4):390-3.

24. Rees T, Hardy L, Güllich A, Abernethy B, Côté J, Woodman T, et al. The Great British Medalists Project: A Re-view of Current Knowledge on the Development of the World's Best Sporting Talent. Sports Med 2016;46(8):1041-58.

25. Monsma EV, Malina RM, Feltz DL. Puberty and physical self-perceptions of competitive female figure skaters: an in-terdisciplinary approach. Res Q Exerc Sport 2006;77(2):158-66.

26. Mirwald RL, Baxter-Jones AD, Bailey DA, Beunen GP. An assessment of maturity from anthropometric measure-ments. Med Sci Sports Exerc 2002;34(4):689-94.

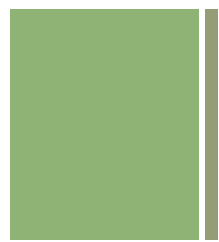

Corresponding author

Felipe Goedert Mendes

Department Physical Education, Sports Center,

Federal University of Santa Catarina

Campus Reitor João David Ferreira Lima, 88040-900 Florianópolis

Florianópolis/Santa Catarina, Brasil

E-mail:Felipe_goedert@hotmail.com 